\title{
LIVELIHOOD STATUS OF FISHERS OF THE PADMA RIVER, SREENAGAR, MUNSHIGANJ
}

\author{
S. Shill*1, A. Sarker², M. Asaduzzaman², G. A. Latifa, \\ S. C. Podder and M. A. Obaida \\ Department of Zoology, University of Dhaka, Dhaka 1000, Bangladesh
}

\begin{abstract}
Data were collected by using well structured questionnaire. Age group of $31-40$ years was the highest (40\%) in Bhagyakul whereas in Mandra the highest was 41 - 50 years $(40 \%)$. The maximum fishermen $(80 \%)$ were Hindu in Bhagyakul while higher percentage of Muslim fishermen (88) was found in Mandra. Education status of this community was very poor, $14 \%$ totally illiterate, $24 \%$ can sign only, $20 \%$ got primary education, and the rest $22 \%$ got secondary and higher secondary education, and no graduate. The majority $(58 \%)$ of the respondents had 'Kacha', 18\% had half-concrete, 10\% had tinshed and only 2\% had concrete house. About $46 \%$ of the fishermen got their health service from village doctor/'Kobiraj', remaining people went to upazila health complex (18\%), district hospital (14\%), and MBBS doctor (20\%), but a few people do not get any treatment $(2 \%)$ due to lack of money. About 18\% fishermen had 'Pakka' toilet, $30 \%$ had 'semi-Pakka', $46 \%$ had 'Kacha' toilet and rest of $12 \%$ had no sanitary facility. The annual income of fishermen in the study area varied from BDT 66,000 $1,05,000$. The fishermen received loan from different national and local NGOs for buying fishing gears and boats.
\end{abstract}

Key words: Community, fishermen livelihood status, Padma River

\section{INTRODUCTION}

Bangladesh has vast freshwater areas of rivers, canals and estuaries. These water bodies are along with their innumerable tributaries from one of the richest habitats of fishes in this sub-continent in respect of freshwater fishery (Rahman 2005). Fish and fisheries are indispensable part in the life and livelihoods of the people of Bangladesh and it is the part of our cultural heritage. Fisheries sector plays an immensely significant role on the socio-economic development of Bangladesh. Fisheries sector contributes about $2.46 \%$ of the total export earning, $4.39 \%$ to GDP and $22.76 \%$ to agricultural sector. Annual fish production was 3.26 million metric tons in the fiscal year 2011-12 (DoF 2013).

About 12 million people directly or indirectly depend on fisheries sector for their livelihood (DoF 2005). Alam and Bashar (1995) estimated that the average per capital annual income of the fishermen families to be BDT 2,442 i.e. about $70 \%$ lower than the per capital income of the country as a whole. Being an isolated community fishermen are deprived of many amenities of life.

"Corresponding author. 1University Grants Commission of Bangladesh, Agargaon, Dhaka, Bangladesh. 2Department of Zoology, Jagannath University, Dhaka-1100, Bangladesh

(C) 2016 Zoological Society of Bangladesh DOI: 10.3329/bjz.v44i1.30175 
Among the all other rivers the Padma is the second longest river of Bangladesh. It is the main distributary of the River Ganges which originates in the Gangotri Glacier of the Himalayan. It has a vast influence in fish supply, water transportation, agriculture and also in cultural practices in Bangladesh. This river is important for Hilsa migration and fishery and at the same time, the fishermen community near the mighty river is well known for Hilsa fishing. Like other important fishes of Bangladesh, the Hilsa shad (Tenualosa ilisha) fishery is by far the largest single species fishery in Bangladesh. The flag-ship species of Bangladesh Hilsa is the most important fish species that links not only the trans-boundary ecosystem of India and Bangladesh but also the life and culture of two neighbouring countries (IUCN, 2011). Every year government take steps to conserve the renowned fishery but very little is known about the fishing community, who are involved in this fishing practice. Considering the above fact, the present study was carried out to assess the livelihood status and constraint faced by the fishermen of two villages, adjacent of River Padma.

\section{MATERIAL AND METHODS}

Study area: This study was conducted for a period of 9 months from April to December, 2015 in two neighbouring villages, namely Mandra and Bhagyakul under Sreenagar Upazila of Munshiganj along the Padma River (Fig. 1).

Data collection: Observation and survey methods were used as principal tools for data collection. Survey was gone through personal interview supplemented by multiple methodological Participatory Rural Appraisal (PRA) tools such as Focus Group Discussion (FGD) and Crosscheck Interviews (CI) with key informants (Lin 1976).

Secondary data collection: The study was based on collection of secondary and primary data. Published materials such as journals, textbooks, newspaper etc were used as secondary source of information. Moreover, appropriate government and non government organization such as Department of Fisheries (DoF) and Local NGOs provided information about the study.

Primary data collection: Field surveys were used for the collection of primary data. For the confirmation of the secondary data, primary data was used also. Questionnaire form was filled in by interviewing 50 fishermen fishing in the Padma river.

Focus group discussion (FGD): For this research one of the PRA tool, such as Focus Group Discussion was conducted with fishermen. In this research, FGD was used to get an overview of the likelihood status of the fishermen of the Padma river. A total of 6 FGD sessions was conducted where each group size of FGD was 6 to 8 men. FGD session was held in front of tea stall, under the shaded area, in the open field, etc. 
Crosscheck interviews: After collecting the data through questionnaire, interviews and FGD, crosscheck interviews were conducted with Upazila Fisheries officers, Field Assistant, relevant NGO workers and school teachers at their office or home.

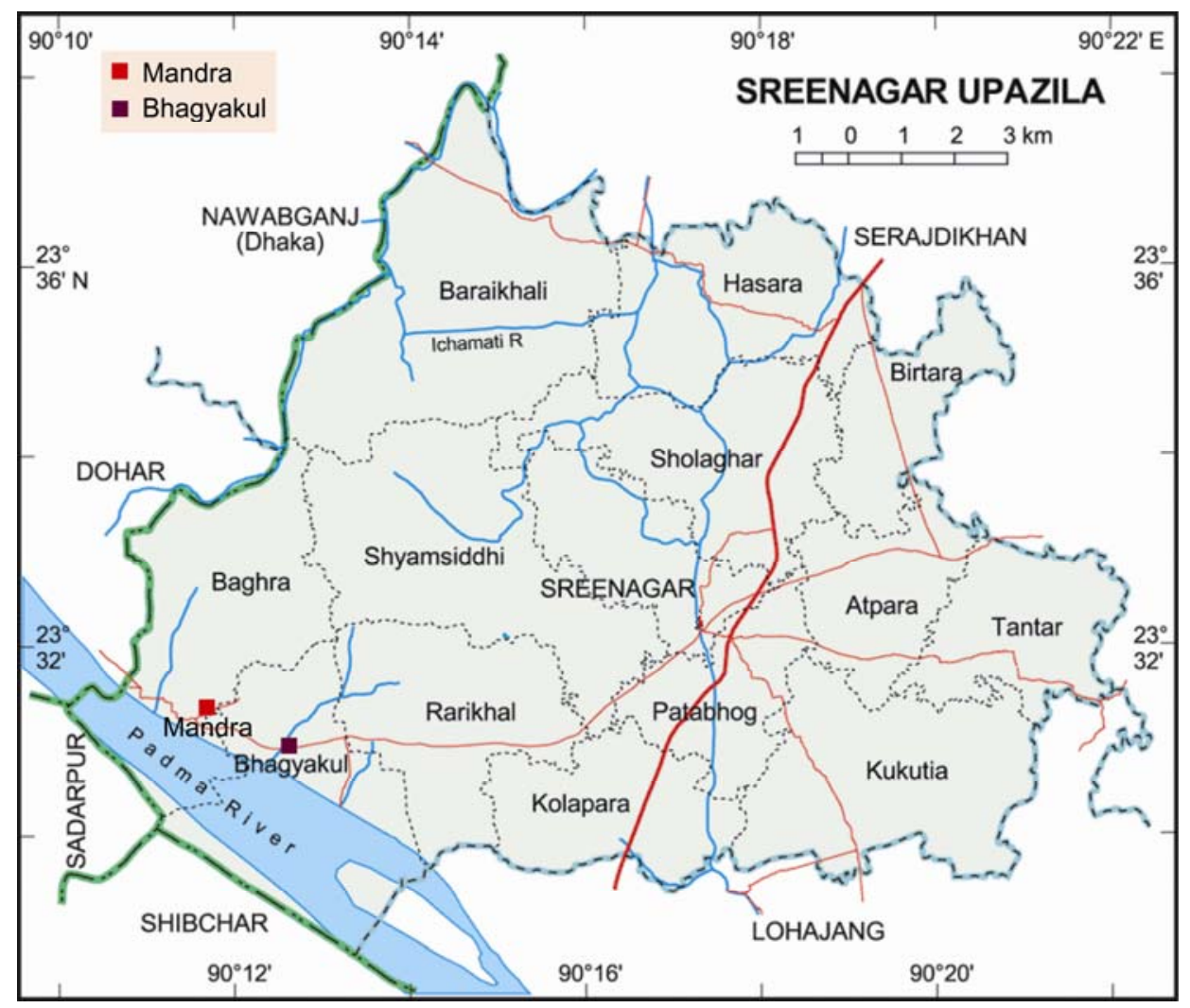

Fig. 1. Mandra and Bhagyakul: Two study areas in the Padma river, Sreenagar Upazila, Munshiganj.

Data analysis: After data collection, these were analyzed by MS Excel and presented in textual, tabular and graphical forms to understand the livelihood status and constraints of the fishers in adjacent area of Padma River.

\section{RESULTS AND DISCUSSION}

\section{Human capital}

Age structure: In estimating potential productive human rsources, the knowledge about age structure of fishermen is important. Different categories of age groups were considered to examine the age structure. It appeared (Fig. 2) that age group of 51- 60 years was the highest 32\% in Bhagyakul whereas in Mandra the largest was 41 - 50 years (40\%). Paul et al. 2013 reported that 
highest age group was 35 - 40 years (30\%) in Birulia and $40-50$ years $(56 \%)$ in Boroibari and Baki et al. (2015) presented that middle age (31 - 40 years) was the highest (48\%). These findings are more or less similar to the present study.

Age

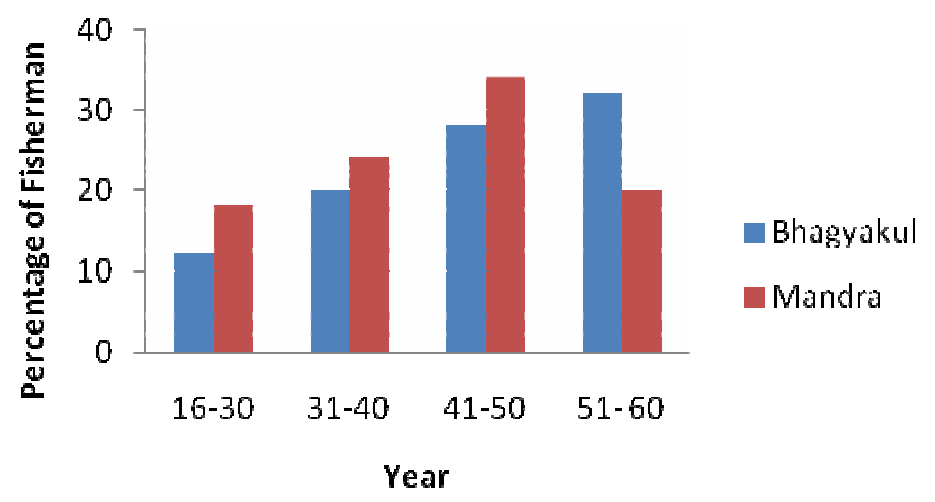

Fig. 2. Age group data of the fishermen in the study areas.

Educational status: Education status of this community is very poor, $14 \%$ is totally illiterate, $24 \%$ can sign only, $40 \%$ get primary education and rest of $22 \%$ is only secondary and higher secondary educated (Table 1). From this research, it was found that, no graduate in this fishing community. Whereas government is committed to ensure $100 \%$ primary education for all the children, as such the scenario of education is not satisfactory. But their education level is better than hoar and island fishing community. Mahbubur (2001) reported that $68 \%$ of hoar fishermen were illiterate and Rahman et al. (2012) showed $66.66 \%$ fishers were illiterate in Nijhum Dwip.

Table 1. Educational status of the fishermen in the study area adjacent to River Padma

\begin{tabular}{llll}
\hline Educational level & Bhagyakul $(\mathrm{n}-25)$ & Mandra $(\mathrm{n}-25)$ & Total $(\mathrm{n}-50)$ \\
\hline Illiterate & $2(8 \%)$ & $5(20 \%)$ & $7(14 \%)$ \\
Sign only & $5(20 \%)$ & $7(28 \%)$ & $12(24 \%)$ \\
Primary & $12(48 \%)$ & $8(32 \%)$ & $20(40 \%)$ \\
Secondary & $6(24 \%)$ & $5(16 \%)$ & $11(22 \%)$ \\
\hline
\end{tabular}

Family size and type: The family sizes of the fishermen were divided into three categories depending on the number of the family members (Fig. 3). About $16 \%$ of the respondents had $2-3$ family members, $68 \%$ had small family with 4-5 members, $16 \%$ had more than 6 family members in Bhagyakul whereas $12 \%$ of the respondents had 2 - 3 family members, $80 \%$ had small family with 4 - 5 members, 8\% had more than 6 family members in Mandra, but Khan et al. 
(2013) found highest percentage (57) of family size was medium (5-7 members) in Tista river fishermen community. Probably it happens because the present study area is very near to Dhaka city, so the nuclear family structure influences the society of fishermen.

About $40 \%$ farmers lived with joint families and 60\% lived with nuclear families in Bhagyakul whereas 32\% farmers lived with joint families and $68 \%$ lived with nuclear families in Mandra (Table 2). Baki et al. (2015) reported about $60 \%$ fishermen lived in nuclear families and $40 \%$ lived with joint families, which was almost similar with the present study.

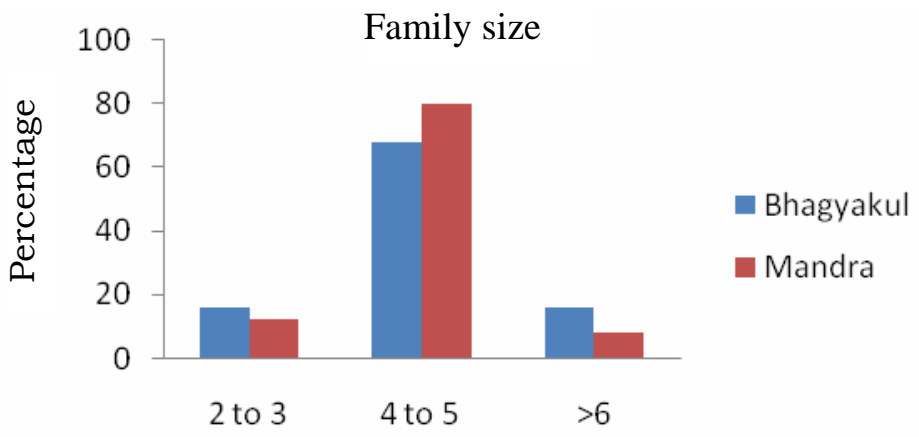

Fig. 3. Family size of the fishermen in the study area.

Table 2. Family status of the fish fishermen in the study area

\begin{tabular}{llll}
\hline Family type & Bhagyakul $(\mathrm{n}-25)$ & Mandra $(\mathrm{n}-25)$ & Total $(\mathrm{N}-50)$ \\
\hline Joint & $2(8 \%)$ & $20(40 \%)$ & $22(44 \%)$ \\
Nuclear & $23(92 \%)$ & $5(20 \%)$ & $28(56 \%)$ \\
\hline
\end{tabular}

Religion

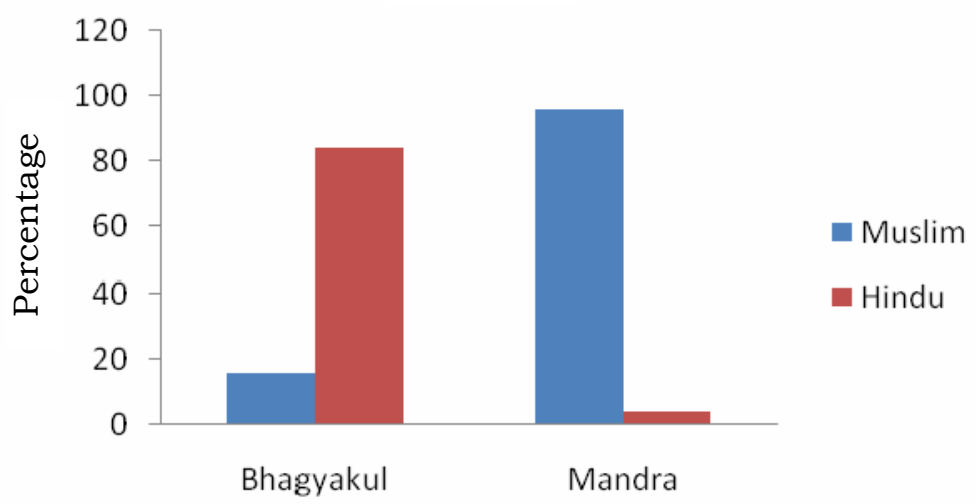

Fig. 4. Religious background status of the fishing community in the study area. 
Religious background status: It was found that maximum fishermen (84\%) were Hindu in Bhagyakul while highest percentage of Muslim fishermen (96) was found in Mandra (Fig. 4). Whereas, according to Paul et al. (2013) Hindus were featuring as the absolute majority of the fishermen. The Hindu fishermen came from lower cast of this community. Hannan (1994) stated that ethnic communities used catch fish from natural water in Bangladesh and that came from a low caste of Hindu society.

\section{Physical capital}

Housing conditions: The majority (58\%) of the respondents had Kacha, 18\% had half building, 10\% had tinshed and only $2 \%$ had building house (Fig. 5). Ali et al. (2008) reported that, about 54\% of the fish farmers in Hamirkustia and Katabari Unions of Bagmara Upzila under Rajshahi district have tinshed house while 26, 14 and $6 \%$ of the farmers have half building, building and Kacha house, respectively which was almost similar to present study. Whereas Baki et al. (2015) found 66\% mud built (Kacha), 34\% semi brick built (tinshed) and no brick built (building) house.

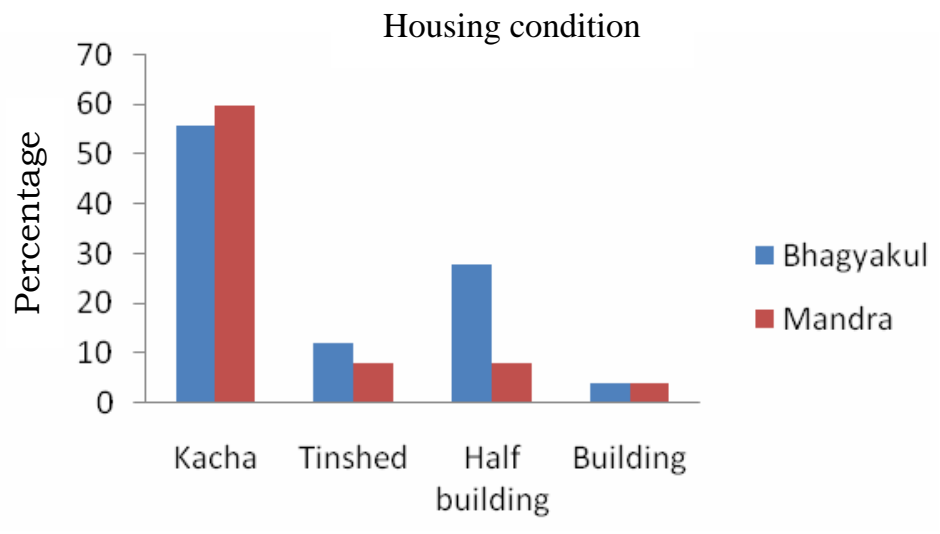

Fig. 5. View of the housing condition of the fishermen community.

Health facilities: Health facilities are very poor for the fishing community due to lack of consciousness and financial support. When the farmers face health problem then initially most of them go to the village doctor/Kobiraj (46\%). If the problem is severe then they go to Upazila health complex (18\%), district hospital $(14 \%)$, and MBBS doctor $(20 \%)$, but a few of them do not get any treatment $(2 \%)$ due to lack of money (Table 3). Similarly, Baki et al. (2015) reported that fishermen have been facing severe health problems and $54 \%$ of the fishermen households were dependent on village doctors who did not have any know-how of medical science, $28 \%$ got health service from Upazila health complex and 
remaining 18\% got service from MBBS doctors. Pravakar et al. (2013) found that health facilities of the fish farmers in the Shahrasti Upazila were poor, most of them $(70 \%)$ dependent on village doctors, while 20 and $10 \%$ got health service from Upazila health complex and MBBS doctors respectively.

Table 3. Health service received by the fish fishermen in the surveyed area

\begin{tabular}{lccc}
\hline Health service & Bhagyakul $(\mathrm{n}-25)$ & Mandra $(\mathrm{n}-25)$ & Total $(\mathrm{N}-50)$ \\
\hline Village doctor/Kobiraj & $12(48 \%)$ & $14(56 \%)$ & $23(46 \%)$ \\
Upazila health complex & $7(28 \%)$ & $6(24 \%)$ & $9(18 \%)$ \\
District hospital & $2(8 \%)$ & $1(4 \%)$ & $7(14 \%)$ \\
MBBS doctor (private) & $3(12 \%)$ & $2(8 \%)$ & $10(20 \%)$ \\
Do not get any treatment & $1(4 \%)$ & $2(8 \%)$ & $1(2 \%)$ \\
\hline
\end{tabular}

Drinking water facilities: In the study area, $12 \%$ of the fishermen used their own tube-well and 88\% used neighbor's tube-well in Bhagyakul and $8 \%$ of the fishermen used own tube-well and 92\% used neighbour's tube well for collecting drinking water (Fig. 6). Similarly, Kabir et al. (2012) found that $100 \%$ fishermen's household used tube-well water for drinking purposes, among them $40 \%$ had their own tube-well, 50\% used shared tube-well and rest of $10 \%$ used neighbor's tube-well.

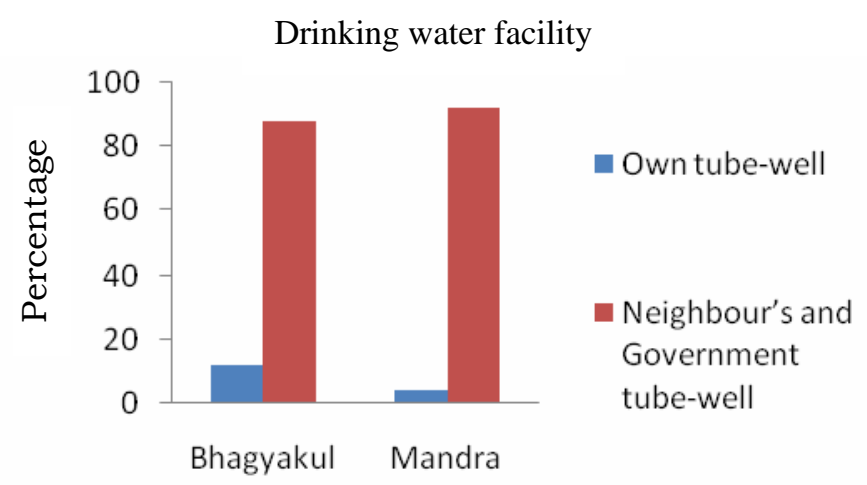

Fig. 6. Drinking water facility of fishermen in the study area.

Electricity facilities and electronic media: In the study area, it was found that $100 \%$ of the surveyed fishermen have electricity facilities. During study period, the fishermen were found to use own radio, mobile phone and television for their recreational purpose and also for getting national news.

Sanitary facilities: Most of the people in the study area have poor sanitation facilities. It was revealed that, 10\% fishermen had 'Pakka' toilet, 14\% had semiPakka, 35\% had Kacha toilet and rest of $12 \%$ had no sanitary facility (Table 4). Households of fishermen often suffered from water mediated-diseases like 
diarrhoea and cholera due to lack of good sanitary facilities, but, according to Ali et al. (2009), the fishermen of Mymensingh district have better sanitary access, $12.5 \%$ had Pakka toilet, $62.5 \%$ had semi-Pakka and 25\% had Kacha toilet.

Table 4. Sanitary facilities of fishermen community in the study areas

\begin{tabular}{lccc}
\hline Sanitary facilities & Bhagyakul $(\mathrm{n}-50)$ & Mandra $(\mathrm{n}-50)$ & Total $(\mathrm{n}-50)$ \\
\hline Open & $1(4 \%)$ & $2(8 \%)$ & $3(12 \%)$ \\
Kacha & $17(68 \%)$ & $18(72 \%)$ & $35(70 \%)$ \\
Semi-Pakka & $8(32 \%)$ & $3(12 \%)$ & $7(14 \%)$ \\
Pakka & $3(12 \%)$ & $2(10 \%)$ & $5(10 \%)$ \\
\hline
\end{tabular}

\section{Financial capital}

Credit facilities: This study revealed that the fishermen of Bhagyakul and Mandra received loan from different NGOs like ASA, GRAMEEN BANK, RIC, BRAC, and some others local NGO for buying fishing gears and boats. During full banning period (March to April) they took loan basically.

Table 5. Secondary occupation by the fishermen in the surveyed area

\begin{tabular}{lccc}
\hline Secondary income source & Bhagyakul (n - 25) & Mandra (n - 25) & Total (n - 50) \\
\hline Agriculture & $6(24 \%)$ & $5(20 \%)$ & $11(22 \%)$ \\
Rickshaw/van pulling & $4(16 \%)$ & $8(32 \%)$ & $12(24 \%)$ \\
Daily labor & $5(20 \%)$ & $7(28 \%)$ & $12(24 \%)$ \\
Net mending & $8(32 \%)$ & $4(16 \%)$ & $12(24 \%)$ \\
Wood carpenter & $2(8 \%)$ & $1(4 \%)$ & $3(6 \%)$ \\
\hline
\end{tabular}

Table 6. Annual income of the fishermen in the study area

\begin{tabular}{lccc}
\hline Level of income (BDT) & Bhagyakul (n - 25) & Mandra (n - 25) & Total (n - 50) \\
\hline $66,000-75,000$ & 0 & 1 & 1 \\
$76,000-85,000$ & 7 & 6 & 13 \\
$86,000-95,000$ & 8 & 13 & 21 \\
$95,000-1,05,000$ & 10 & 5 & 15 \\
\hline
\end{tabular}

Income sources: The fishermen try their best to lead a smooth life, but they do not do that due to their poor income. In the study area, cent per cent fishermen's main income source was fishing. In the present situation they cannot cope with increase of the price of the daily necessary commodity, so they involved in secondary occupation like agriculture $(22 \%)$, rickshaw and van pulling $(24 \%)$, daily labor (24\%), net mending (24\%), wood carpenter $(6 \%)$ etc (Table 5). The average incomes of the fishermen varied from BDT 66,000 $1,05,000$ annually (Table 6). Baki et al. (2015) reported the annual income of fishermen varied from BDT 60,000 to 85,000 . 
Fishing equipment: Several forms of nets are being used by the fishermen as Sandrijal, Poajal, Jhakijal, Current jal, Moiyajal, Gultijal, Gill nets, Current nets, Borshi, wounding gear etc.

Livelihood constraints of the fishermen: Most of the fishermen were facing various problems during fishing and marketing their goods in the local markets. The main problems have been identified from the fishermen during the study period are lack of sufficient fishing craft (Boat), lack of fishing gears, natural calamities (flood, storm, cyclone etc.), water pollution, increasing Char land, Lack of credit facilities, lack of training facilities, use of current Jal an disturbances by dacoit and thieves and sometimes by local people themselves. Most of the fishermen are very poor and they have limited resources to buy nets and other fishing equipments. They are ignored in respect of the society. Most of them are illiterate and live from hand to mouth. Being very poor, their children often go for fishing rather than going to school. As a result, generation after generation, they remain illiterate and not being able to contribute for the improvement of their community. According to Khan et al. (1994), overfishing by increasing population and exploitation of the fishermen by money lenders are imposing threat to livelihood of poor fishers.

\section{CONCLUSION}

The livelihood status of the fishermen of Bhagyakul and Mandra was not satisfactory. The education level of the fishermen was poor. Due to lack of awareness as well as the poor income of the fishermen, children do not go to school. The government should take some important steps by taking some sorts of management policies as well as providing of some extra providence during the fishing ban period.

Acknowledgements: Authors are grateful to Faunal Survey and Enrichment of Facilities for Biodiversity Research Sub-project (CP 2216), HEQEP, UGC for the financial support.

\section{LITERATURE CITED}

ALAM, M.F. and BASHAR, M.A. 1995. Structure of cost and profitability of small scale riverine fishing in Bangladesh. J. Res. Prog. 9: 235-241.

ALI, M.H., HOSSAIN, M.D., HASAN, A.N.G.M. and BASHAR, M.A. 2008. Assessment of the livelihood status of the fish farmers in some selected areas of Bagmara upazila under Rajshahi district. J. Bangladesh Agricultural University 6(2): 367-374.

ALI, H., AZAD, M.A.K., ANISUZZMAN, M., CHOWDHURY, M.M.R., HOQUE, M. and SHRIFUL, M. I. 2009. Livelihood status of the fish farmers in some selected areas of Tarakanda upazila of Mymensingh district. J. Agroforestry and Environment 3(2): 85-89.

BBS (Bangladesh Bureau of Statistics), 2002. Statistical Yearbook of Bangladesh. Bureau of Statistics. Statistical Division, Ministry of Planning, The Government of the People's Republic of Bangladesh, Dhaka. 660 pp. 
BAKI, M.A., ISLAM, M. R., HOSSAIN, M. M. and BHOUIYAN, N.A. 2015. Livelihood status and assessment of fishing community in adjacent areas of Turag-Burigonga River, Dhaka, Bangladesh. Int. J. Pure and Applied Zoology 3(4): 347-353.

DoF (Department of Fisheries). 2005. Fisheries Fortnight Compendium, Department of Fisheries. Ministry of Fisheries and Livestock, Dhaka, Bangladesh.

DoF (Department of Fisheries). 2013. National Fish Week 2013 Compendium (In Bengali). Ministry of Fisheries and Livestock, Bangladesh. $144 \mathrm{pp}$.

HANNAN, M. 1994. Fisher folk organization in Bangladesh. In: Socio-economic Issues in Coastal Fisheries Management. Proc. of the IPFC Symposium, Bangkok, Thailand, 23-26 November 1993; FAO Indo-Pacific Fishery Commission (IPFC) 8: 216-222.

IUCN. 2011. The importance of migratory and spawning patterns for the conservation of Hilsa in Bangladesh and India. International Union for Conservation of Nature (IUCN), Asia. pp. 1-7.

KABIR, K.R., ADHIKARY, R.K., HOSSAIN, M.B. and MINAR, M.H. 2012. Livelihood status of fishermen of the old Brahmaputra River, Bangladesh. World Applied Sciences J. 16(6): 869-873.

KHAN, M.A.R., MIAH, M.I., HOSSAIN, M.B., BEGUM, A., MINAR, M.H. and KARIM, R. 2013. Fish biodiversity and livelihood status of fishing community of Tista River, Bangladesh. Global Veterinaria 10(4): 417-423.

KHAN, M.S., HAQ, E., RAHMAN, A.A., RASHID, S.M.A. and AHMED, H. 1994. Wetlands of Bangladesh. Bangladesh Centre for Advanced Studies (BCAS), Dhaka, Holiday Printers limited. pp. 2-57.

LIN, N. 1976. Foundations of Social Research. McGraw Hill Book Company, New York.

MAHABUBUR, M.R. 2001. Study on the fisheries and socio-economic condition of the Fishermen in the Baculiarhaor, Itna, Kishorgonj. M.S Thesis, Department of Fisheries Management, Bangladesh Agricultural University, Mymensingh. pp. 51.

PAUL, B., HASAN, F. and DEWWAN, A.A. 2013. Livelihood status of the Fishermen of the Turag River, Bangladesh. Middle-East J. of Scientific Research 18(5): 578-583.

PRAVAKAR, P., SARKER, B.S., RAHMAN, M. and HOSSIN, M.B. 2013. Present Status of fish farming and livelihood of fish farmers in Shhrasrti Upzilla of Chandpur district, Bangladesh. American-Eurasian J. Agricultural and Environmental Sciences 13(3): 391-397.

RAHMAN, A.K.A. 2005. Freshwater Fishes of Bangladesh. 2nd ed. Zool. Soc. Bangladesh, Dhaka, Bangladesh. 394+xviii pp.

RAHMAN, M., RAHMAN, M.M., HASAN, M.M., and ISLAIM, M.R. 2012. Livelihood of the Potential of Alternative Income Generating Activities of Father's Community of Nijhum Dwip under Hatiya Upazila of Noakhali district in Bangladesh. Bangladesh Research Publications J. 6: 370-379. 